\title{
Faults diagnostics of high-voltage equipment based on the analysis of the dynamics of changing of the content of gases
}

\section{Oleg Shutenko}

Department of Electric Power Transmission, National Technical University

"Kharkiv Polytechnic Institute",

Kharkiv, Ukraine

Email: o.v.shutenko@gmail.com
In the article, the gas content of oils in high-voltage equipment with defects of different types is analysed. Typical gas contents and gas ratios for 38 most frequently encountered defects are presented and analysed. The dynamics of the gas content change in equipment during the development of defects was investigated. It is concluded that the development of defects in high-voltage equipment is accompanied by the growth of gas concentrations, which is known and widely used, and it helps stabilize the percentage of gases at strictly defined levels and detect defects at an early stage.

Keywords: dissolved gas analysis, faults diagnostics, high-voltage equipment, fault diagnosis, gas ratios, gas percentage, dynamics of gas content change

\section{INTRODUCTION}

Detection and identification of defects in high-voltage equipment, especially at an early stage of their development, is an actual and practically significant scientific and technical task. Since most of the defect developing in equipment is accompanied by the release of gases that are formed as a result of the destruction of insulation, one of the most common and widely used methods of diagnostics is the dissolved gas analysis in oil (DGA). At present, analytical and graphical recognition methods are used to identify the type of defect that is predicted by the results of DGA. Analytical methods use values of gas ratios, which are regulated by known standards [1-6]. Some graphical me- thods, for example, the Dornenburg rectangle [3], the ETRA square [5], also use the gas ratios as coordinates for the diagnosed equipment. In most of the known graphical methods, such as the triangle of GATRON [7], Duval triangle [8], Duval pentagon [9], the percentage of gases is used to determine the type of defects as the coordinates of the diagnosed equipment. A significant drawback of these methods is an incomplete use of diagnostic information. The key gas method uses the percentage of five gases [10]. But this method allows you to recognize only 4 defects. It should be noted that all methods described do not take into account the dynamics of the change of the gas content of oils in time for equipment with defects of different types. This circumstance does not allow to identify defects 
at an early stage of their development, which was the reason for writing this article.

\section{ANALYSIS OF THE GAS CONTENT OF EQUIPMENT WITH DEFECTS OF DIFFERENT TYPES}

At the first stage of the study, the percentage of gases in equipment oil was assessed, in which defects were found by the results of DGA. For this purpose, the results of DGA were used for 2160 units of high-voltage equipment, in which defects of various types were detected. Table 1 shows the distribution of defective equipment by the criterion of gas with the maximum content. As it is shown in Table 1, in the sample presented for the analysis, the greatest amount of equipment had defects for which, according to the results of DGA, the gas with the maximum content was hydrogen (736 units or $34.076 \%$ ). A somewhat smaller number of defects were associated with a maximum ethylene content (687 units or $31.806 \%$ ). The number of equipment with defects for which the gases with the maximum content were ethane and acetylene was approximately the same (224 units or 10.37\% for ethane and 219 units or $10.139 \%$ for acetylene). The maximum content of methane was found in 294 units of equipment, which was $13.611 \%$. For each object from Table 1, the percentage of each of the gases in the oil sample was calculated:

$$
A_{i \%}=100 \frac{A_{i}}{\sum}
$$

where $A_{i \%}$ is the percentage of gas, $A_{i}$ is the concentration of gas, and $\Sigma$ is the sum of the concentrations of hydrocarbon gas and hydrogen in the oil sample.

Table 1. Distribution of defective equipment by the criterion of gas with the maximum content

\begin{tabular}{c|cc}
\hline No. & $\begin{array}{c}\text { Gas with the maximum } \\
\text { content }\end{array}$ & Number of equipment \\
\hline 1 & Hydrogen $\left(\mathrm{H}_{2}\right)$ & 736 \\
\hline 2 & Methane $\left(\mathrm{CH}_{4}\right)$ & 294 \\
\hline 3 & Ethane $\left(\mathrm{C}_{2} \mathrm{H}_{6}\right)$ & 224 \\
\hline 4 & Ethylene $\left(\mathrm{C}_{2} \mathrm{H}_{4}\right)$ & 687 \\
\hline 5 & Acetylene $\left(\mathrm{C}_{2} \mathrm{H}_{2}\right)$ & 219 \\
\hline & Total & 2160 \\
\hline
\end{tabular}

The performed analysis showed that for different equipment with the same type of defect, despite the fact that the values of gas concentrations can differ significantly from each other, the values of the percentage of gases were approximately the same. For example, Table 2 shows the values of gas concentrations and their percentage in different oil-filled equipment in which partial discharges were detected.

At the same time, as it is shown in Table 2, the values of percentage of gases for the same type of defect are not constant and may differ. The main reasons for the identified differences $[11,12]$ are: individual features of the development of the defect, differences in the amount of energy which is released in the process of developing of the defect, the sort of transformer oils, design features, different materials, and other factors. In this regard, the percentage content of gases for defects of different types is more appropriate to be specified not as strictly fixed values of the percentage of gases, as in the key gas method, but in the form of minimum and maximum ranges of values. The analysis made it possible to establish typical gas content for more than 100 different defects and their combinations. However, due to the limited volume of the article, Table 3 shows the percentages of gas contents only for 38 most common defects. The bold font in Table 3 highlights the gases with the maximum content. In addition to electric discharges with different energy densities and overheating with different temperatures, Table 3 shows the percentage of gases for defects in which overheating is accompanied by electric discharges, and vice versa. For convenience of analysing the types of defects from Table 3, Table 4 shows the values of the gas ratios: $\mathrm{C}_{2} \mathrm{H}_{2} /$ $\mathrm{C}_{2} \mathrm{H}_{4}, \mathrm{CH}_{4} / \mathrm{H}_{2}, \mathrm{C}_{2} \mathrm{H}_{4} / \mathrm{C}_{2} \mathrm{H}_{6}, \mathrm{C}_{2} \mathrm{H}_{2} / \mathrm{C}_{2} \mathrm{H}_{4}, \mathrm{C}_{2} \mathrm{H}_{2} / \mathrm{C}_{2} \mathrm{H}_{6}$ and $\mathrm{C}_{2} \mathrm{H}_{6} / \mathrm{CH}_{4}$, which are used in known standards [1-6]. As in Table 3, the values of the gas ratios are given in the form of ranges, including the minimum and maximum values. To reduce the error, the values of the gas ratios were calculated if the values of gas concentrations exceeded the following values: $\mathrm{H}_{2}>0.005 \%$ vol., $\mathrm{CH}_{4}, \mathrm{C}_{2} \mathrm{H}_{6}$ and $\mathrm{C}_{2} \mathrm{H}_{4}>0.0015 \%$ vol., and $\mathrm{C}_{2} \mathrm{H}_{2}>0.0003 \%$ vol. [5]. Most of the defects which are given in Table 3 have been thoroughly studied and described in literature. As a rule, their identification is not particularly difficult. In connection with this, 
Faults diagnostics of high-voltage equipment based on the analysis of the dynamics of changing of the content of gases 13

Table 2. Values of gas concentrations and their percentage in equipment with partial discharges

\begin{tabular}{|c|c|c|c|c|c|c|c|c|c|c|}
\hline \multirow{2}{*}{ Equipment } & \multicolumn{5}{|c|}{ Values of gas concentrations, $\%$ vol. } & \multicolumn{5}{|c|}{ Content of gases, $\%$} \\
\hline & $\mathrm{H}_{2}$ & $\mathrm{CH}_{4}$ & $\mathrm{C}_{2} \mathrm{H}_{6}$ & $\mathrm{C}_{2} \mathrm{H}_{4}$ & $\mathrm{C}_{2} \mathrm{H}_{2}$ & $\mathrm{H}_{2}$ & $\mathrm{CH}_{2}$ & $\mathrm{C}_{2} \mathrm{H}_{6}$ & $\mathrm{C}_{2} \mathrm{H}_{4}$ & $\mathrm{C}_{2} \mathrm{H}_{2}$ \\
\hline Transformer 220 kV, 40 MVA & 0.0681 & 0.00197 & 0.00011 & 0.00021 & 0 & 96.747 & 2.799 & 0.156 & 0.298 & 0.000 \\
\hline $\begin{array}{c}\text { Transformer } 220 / 33 \mathrm{kV} \\
50 \mathrm{MVA}\end{array}$ & 0.0041 & 0.0002 & $110^{-7}$ & $110^{-7}$ & $110^{-7}$ & 95.342 & 4.651 & 0.002 & 0.002 & 0.002 \\
\hline Bushing $220 \mathrm{kV}$ & 0.095 & 0.0037 & 0.00136 & 0.0012 & 0 & 93.818 & 3.654 & 1.343 & 1.185 & 0.000 \\
\hline Bushing $330 \mathrm{kV}$ & 5.5657 & 0.3595 & 0.0166 & 0.0004 & 0 & 93.664 & 6.050 & 0.279 & 0.007 & 0.000 \\
\hline Bushing $110 \mathrm{kV}$ & 0.4835 & 0.0294 & 0.0032 & 0.0003 & 0 & 93.629 & 5.693 & 0.620 & 0.058 & 0.000 \\
\hline Current transformer $110 \mathrm{kV}$ & 1.2 & 0.0754 & 0.023 & 0.0002 & 0.0001 & 92.400 & 5.806 & 1.771 & 0.015 & 0.008 \\
\hline
\end{tabular}

only those defects that are difficult to identify are discussed below.

When analysing defects for which, in DGA samples, the gas with the maximum content is hydrogen (1-8), special attention should be paid to defect No. 5 (low-energy discharges). This defect is caused by insulation damage in the transform- ers [13], which is the cause of their accidental damage. In the oil samples of equipment with this defect, a high content of hydrogen and methane, a slightly lower ethane and acetylene content, and a low ethylene content were observed (see Table 3). As it is shown in Table 4, for this defect the values of the ratios were $\mathrm{CH}_{4} / \mathrm{H}_{2}>0.5$ and

Table 3. Percentage of gases in equipment with defects of different types

\begin{tabular}{|c|c|c|c|c|c|c|}
\hline \multirow{2}{*}{ No. } & \multirow{2}{*}{ Fault type } & \multicolumn{5}{|c|}{ Content of gases, \% } \\
\hline & & $\mathbf{H}_{2}$ & $\mathrm{CH}_{4}$ & $\mathrm{C}_{2} \mathrm{H}_{6}$ & $\mathrm{C}_{2} \mathrm{H}_{4}$ & $\mathrm{C}_{2} \mathrm{H}_{2}$ \\
\hline 1 & Low-energy partial discharge deposition of X-wax & $85-95$ & $1-9$ & $0-3.5$ & $0-1.8$ & $0-1.5$ \\
\hline 2 & High-energy partial discharge & $55-98$ & $0.2-8$ & $0-6$ & $0.07-5$ & $0.1-32$ \\
\hline 3 & Spark discharges & $26-73$ & $8-32$ & $2-15$ & $5-30$ & $1-21$ \\
\hline 4 & Surface discharge, creeping discharge & $29-74$ & $5-42$ & $0-5.5$ & $5.5-35$ & $2-25$ \\
\hline 5 & Low-energy discharge & $33-48$ & $32-45$ & $5-22$ & $0,3-3$ & $0.5-13$ \\
\hline 6 & Low-energy discharge & $34-74$ & $5-25$ & $1.5-15$ & $1,8-15$ & $5-36$ \\
\hline 7 & Low-energy arcing & $44-94$ & $1-8$ & $0-3$ & $0.1-22$ & $0.5-44$ \\
\hline 8 & High-energy discharge, arcing & $30-78$ & $3-29$ & $0-14$ & $0.5-28$ & $10-45$ \\
\hline 9 & Partial discharge, corona in oil & $0.1-7$ & $80-95$ & $0.9-15$ & $0.1-3$ & $0-0.8$ \\
\hline 10 & Overheating and discharge & $10-40$ & $35-80$ & $3-25$ & $0-15$ & $0-3$ \\
\hline 11 & Overheating $150-300^{\circ} \mathrm{C}$ & $0-9$ & $50-80$ & $14-35$ & $14-35$ & $0-0.1$ \\
\hline 12 & Overheating $150-300^{\circ} \mathrm{C}$ & $0-35$ & $27-54$ & $26-45$ & $0-23$ & $0-2.2$ \\
\hline 13 & Overheating $300-700^{\circ} \mathrm{C}$ & $10-40$ & $25-75$ & $0-25$ & $5-40$ & $0-3.5$ \\
\hline 14 & Overheating $>700^{\circ} \mathrm{C}$ & $10-35$ & $30-55$ & $4-8$ & $25-40$ & $0-2$ \\
\hline 15 & Overheating and discharge & $0-10$ & $32-80$ & $0.02-25$ & $6.7-43$ & $1-18$ \\
\hline 16 & Overheating and arcing & $21-35$ & $25-45$ & $0.05-15$ & $20-35$ & $12-20$ \\
\hline 17 & Overheating $200-300^{\circ} \mathrm{C}$ & $10-30$ & $12-40$ & $30-70$ & $1.5-25$ & $0-1.1$ \\
\hline 18 & Overheating $200-300^{\circ} \mathrm{C}$ & $0-10$ & $1.5-27$ & $35-98$ & $2.5-40$ & $0-1.3$ \\
\hline 19 & Partial discharge, deposition of X-wax & $25-45$ & $3-15$ & $49-62$ & $0.01-0.6$ & $0-0.5$ \\
\hline 20 & Overheating and partial discharge & $10-40$ & $1-23$ & $25-50$ & $5-23$ & $4-25$ \\
\hline 21 & Overheating and discharge & $1.0-15$ & $3-32$ & $45-75$ & $2-15$ & $5-17$ \\
\hline 22 & Overheating and arcing & $10-30$ & $7-15$ & $25-35$ & $14-21$ & $20-32$ \\
\hline
\end{tabular}


Table 3. (continued)

\begin{tabular}{|c|c|c|c|c|c|c|}
\hline \multirow{2}{*}{ No. } & \multirow{2}{*}{ Fault type } & \multicolumn{5}{|c|}{ Content of gases, $\%$} \\
\hline & & $\mathrm{H}_{2}$ & $\mathrm{CH}_{4}$ & $\mathrm{C}_{2} \mathrm{H}_{6}$ & $\mathrm{C}_{2} \mathrm{H}_{4}$ & $\mathrm{C}_{2} \mathrm{H}_{2}$ \\
\hline 23 & Overheating $500-700^{\circ} \mathrm{C}$ & $10-30$ & $20-40$ & $7-25$ & $25-50$ & $0-3.5$ \\
\hline 24 & Overheating $500-700^{\circ} \mathrm{C}$ and discharge & $5-26$ & $20-30$ & $5-18$ & $30-46$ & $3-9$ \\
\hline 25 & Overheating $>700^{\circ} \mathrm{C}$ & $10-30$ & $25-40$ & $1-10$ & $40-60$ & $0-2.2$ \\
\hline 26 & Overheating $>700^{\circ} \mathrm{C}$ & $0-10$ & $8-30$ & $0.05-13$ & $50-85$ & $0-5.8$ \\
\hline 27 & Overheating $>700^{\circ} \mathrm{C}$ and partial discharge & $0-12$ & $6-20$ & $5-17$ & $52-78$ & $0-12$ \\
\hline 28 & Discharge and overheating $>700^{\circ} \mathrm{C}$ & $19-35$ & $15-30$ & $3-10$ & $30-55$ & $0-10$ \\
\hline 29 & Discharge and overheating $>700^{\circ} \mathrm{C}$ & $5-48$ & $0-21$ & $0-12$ & $35-92$ & $0-12$ \\
\hline 30 & High-energy discharge and overheating $>700^{\circ} \mathrm{C}$ & $7-30$ & $4-9$ & $5-20$ & $30-55$ & $14-40$ \\
\hline 31 & High-energy discharge and overheating $>700^{\circ} \mathrm{C}$ & $20-35$ & $10-25$ & $0.9-10$ & $25-40$ & $12-30$ \\
\hline 32 & Partial discharge & $15-35$ & $1.5-8$ & $1.1-8$ & $0.8-3$ & $55-75$ \\
\hline 33 & Discharge & $5-20$ & $4-16$ & $20-32$ & $10-22$ & $25-50$ \\
\hline 34 & Discharge and overheating & $0-25$ & $20-40$ & $0.1-5$ & $4-22$ & $28-53$ \\
\hline 35 & Discharge and overheating & $6-22$ & $15-28$ & $0.75-6$ & $20-35$ & $25-50$ \\
\hline 36 & Discharge and overheating & $0.1-11.6$ & $1.5-17$ & $0-8$ & $3-35$ & $45-93$ \\
\hline 37 & High-energy discharge & $0-2$ & $0-1$ & $0-5$ & $1-45$ & $50-98$ \\
\hline 38 & High-energy discharge, arcing & $4-43$ & $1-22$ & $0-10$ & $4-36$ & $25-88$ \\
\hline
\end{tabular}

$\mathrm{C}_{2} \mathrm{H}_{2} / \mathrm{C}_{2} \mathrm{H}_{4}>1$, which indicate the presence of discharges, and $\mathrm{C}_{2} \mathrm{H}_{4} / \mathrm{C}_{2} \mathrm{H}_{6}<1$, which is characteristic of partial discharges. Such values of gas ratios do not correspond to known diagnostic schemes [1-6], which makes it difficult to recognize this defect. Tables 3-4 also show spark discharges (continuous sparking in oil between compounds of different potentials or floating potential, oil breakdown between solid materials) for which $\mathrm{C}_{2} \mathrm{H}_{4} / \mathrm{C}_{2} \mathrm{H}_{6}$ values are 1-4 [6] and creeping discharges (discharges over the surface and in the thickness of the paper insulation) for which $\mathrm{C}_{2} \mathrm{H}_{4} / \mathrm{C}_{2} \mathrm{H}_{6}>5$ [5]. In addition, attention should be paid to defect No. 7 (low-energy arcing). As it is shown in Table 3, the gas content of equipment with this defect is characterized by a high content of hydrogen, ethylene and acetylene, which is typical of high-energy discharges. However, because of the low methane content, the ratio $\mathrm{CH}_{4} / \mathrm{H}_{2}<0.1$ (see Table 4), which causes difficulties in recognizing this defect. For example in [14], a similar defect is identified as a partial discharge, in [15] as an arcing discharge, and in [16] as an arcing of low energy.

When analysing defects for which, according to DGA results, the gas with the maximum content is methane (9-16), defect No. 9 (partial dis- charges) should be identified. According to most known standards [1-6], for equipment with partial discharges, the value of the ratio $\mathrm{CH}_{4} /$ $\mathrm{H}_{2}$ does not exceed 0.1. However, it is shown in Table 4 that for the given defect the value of $\mathrm{CH}_{4} / \mathrm{H}_{2}$ ratio is much greater than one, which, according to [1-6], is typical of thermal defects. At the same time, in works $[17,18]$ such defects were identified as partial discharges with low energy or corona in oil. Also note the defect No. 14 (overheating with temperature above $700^{\circ} \mathrm{C}$ ), for which the gas with the maximum concentration is methane. According to existing ideas about the mechanism of gas formation in oil-filled equipment $[19,20]$, at a defect temperature of $500-600^{\circ} \mathrm{C}$, ethylene becomes the gas with the maximum concentration, and at a temperature above $700^{\circ} \mathrm{C}$, the values of the ratio $\mathrm{C}_{2} \mathrm{H}_{4} / \mathrm{C}_{2} \mathrm{H}_{6}>4$. At the same time, as it is shown in Tables 3 and 4, for these defects, the gas with the maximum concentration is methane and the ratio $\mathrm{C}_{2} \mathrm{H}_{4} / \mathrm{C}_{2} \mathrm{H}_{6}>4$. The results of DGA for such defects are given in $[21,22]$.

According to the results of DGA, in equipment in which the gas with the maximum content is ethane (17-22), such defects as overheating in the temperature range $150-300^{\circ} \mathrm{C}$ and 
Faults diagnostics of high-voltage equipment based on the analysis of the dynamics of changing of the content of gases 15

Table 4. Values of gas ratios in equipment with defects of different types

\begin{tabular}{|c|c|c|c|c|c|c|}
\hline \multirow{2}{*}{ No. } & \multicolumn{6}{|c|}{ Gas ratios } \\
\hline & $\mathrm{CH}_{4} / \mathrm{H}_{2}$ & $\mathrm{C}_{2} \mathrm{H}_{6} / \mathrm{CH}_{4}$ & $\mathrm{C}_{2} \mathrm{H}_{4} / \mathrm{C}_{2} \mathrm{H}_{6}$ & $\mathrm{C}_{2} \mathrm{H}_{2} / \mathrm{CH}_{4}$ & $\mathrm{C}_{2} \mathrm{H}_{2} / \mathrm{C}_{2} \mathrm{H}_{6}$ & $\mathrm{C}_{2} \mathrm{H}_{2} / \mathrm{C}_{2} \mathrm{H}_{4}$ \\
\hline 1 & $0.018-0.098$ & $0.03-0.56$ & $0.464-0.844$ & $0.001-0.211$ & $0.009-0.55$ & $0.014-0.095$ \\
\hline 2 & 0.009-0.09 & $0.27-0.87$ & $0.11-0.94$ & $0.01-3.2$ & $0.03-7$ & $0.15-10.7$ \\
\hline 3 & $0.12-0.93$ & $0.096-0.89$ & $1.5-4.92$ & $0.06-1.5$ & $0.28-3.73$ & $0.18-0.99$ \\
\hline 4 & $0.125-0.86$ & $0.037-0.35$ & $5.2-14.1$ & $0.025-3.572$ & $0.656-11.5$ & $0.104-0.982$ \\
\hline 5 & $0.92-0.98$ & $0.14-0.63$ & $0.06-0.23$ & $0.014-0.39$ & $0.08-0.63$ & $1.1-9.9$ \\
\hline 6 & $0.12-0.509$ & $0.107-0.68$ & $1.0-1.88$ & $0.39-4.1$ & $2.06-7.29$ & $1.1-4.91$ \\
\hline 7 & $0.01-0.099$ & $0.11-1.03$ & $3.4-13.6$ & $1.56-30.5$ & $13.5-85.6$ & $1.3-11.6$ \\
\hline 8 & $0.1-0.78$ & $0.068-0.96$ & $2.8-22.0$ & $0.503-8.2$ & $3.1-69.6$ & $1.02-12.6$ \\
\hline 9 & $12-20$ & $0.04-0.2$ & $0.2-0.75$ & $0.003-0.01$ & $0.01-0.25$ & - \\
\hline 10 & $1.1-6.7$ & $0.04-0.56$ & $0.21-0.77$ & $0.0006-0.04$ & $0.001-0.25$ & $0.006-0.18$ \\
\hline 11 & $6.5-9$ & $0.18-0.60$ & $0.19-0.41$ & - & - & - \\
\hline 12 & $1.35-13.8$ & $0.68-0.99$ & $0.1-0.5$ & $0.001-0.005$ & $0.001-0.008$ & $0.003-0.008$ \\
\hline 13 & $1.4-6.6$ & $0.07-0.87$ & $1.03-3.4$ & $0.002-0.078$ & $0.005-0.130$ & $0.002-0.096$ \\
\hline 14 & $1.07-4.2$ & $0.1-0.2$ & $4.3-8.02$ & $0.0007-0.055$ & $0.006-0.45$ & $0.0014-0.056$ \\
\hline 15 & $4.5-7.78$ & $0.03-0.69$ & $1.3-21.1$ & $0.012-0.44$ & $0.25-7.05$ & $0.12-0.75$ \\
\hline 16 & 1.09-1.7 & $0.35-0.42$ & $2.0-8.2$ & $0.19-0.72$ & $0.52-5.9$ & $0.22-0.73$ \\
\hline 17 & $1.0-2.68$ & $1.03-4.26$ & $0.05-0.78$ & $0.0001-0.003$ & $0.0001-0.003$ & $0.002-0.004$ \\
\hline 18 & $1.9-3$ & $1.4-70$ & $0.188-0.91$ & $0.021-0.098$ & $0.001-0.012$ & $0.02-0.05$ \\
\hline 19 & $0.2-0.48$ & $3.9-7.6$ & $0.001-0.003$ & $0.005-0.09$ & - & - \\
\hline 20 & $0.1-0.4$ & $1.2-2.8$ & $0.37-0.67$ & $0.5-1.46$ & $0.298-0.525$ & $0.75-0.96$ \\
\hline 21 & $1.5-2.55$ & $1.46-7.5$ & $0.048-0.21$ & $0.234-1.0$ & $0.097-0.250$ & $1.0-3.326$ \\
\hline 22 & $0.2-0.93$ & $2.32-4.21$ & $0.5-0.739$ & $2.22-3.58$ & $0.719-0.981$ & $1.32-1.60$ \\
\hline 23 & $1.03-3.55$ & $0.26-0.87$ & $1.2-3.9$ & $0.003-0.09$ & $0.004-0.24$ & $0.003-0.082$ \\
\hline 24 & $1.3-3.5$ & $2.5-2.7$ & $0.7-0.75$ & $0.23-0.42$ & $0.32-0.58$ & $0.12-0.22$ \\
\hline 25 & $1.04-3.2$ & $0.05-0.35$ & $4.01-24.1$ & $0.0001-0.09$ & $0.002-0.53$ & $0.0001-0.045$ \\
\hline 26 & $1.59-41$ & $0.11-0.728$ & $4.8-21.2$ & $0.0002-0.66$ & $0.0015-0.7$ & $0.0001-0.07$ \\
\hline 27 & $1.2-4.5$ & $0.8-0.96$ & $4.0-13.6$ & $0.0005-0.73$ & $0.0007-0.75$ & $0.0001-0.21$ \\
\hline 28 & $0.76-0.99$ & $0.16-0.61$ & $4.1-17.5$ & $0.03-0.377$ & $0.13-0.63$ & $0.01-0.13$ \\
\hline 29 & $0.17-0.87$ & $0.17-0.98$ & $4.09-15.5$ & $0.025-0.65$ & $0.05-1.0$ & $0.009-0.2$ \\
\hline 30 & $0.2-0.89$ & $1.03-1.5$ & $4.6-7.2$ & $2.3-6.2$ & $0.7-6.5$ & $0.2-0.96$ \\
\hline 31 & $0.3-0.98$ & $0.12-0.49$ & $6.2-12.9$ & $0.49-2.6$ & $1.3-7.9$ & $0.34-0.97$ \\
\hline 32 & $0.05-0.3$ & $0.63-0.75$ & $0.25-0.75$ & $6.5-37.5$ & $17.3-59.1$ & $26-78$ \\
\hline 33 & $0.78-0.922$ & $2.0-6.14$ & $0.49-0.79$ & $2.4-11.5$ & $1.04-1.9$ & $1.34-3.23$ \\
\hline 34 & $1.05-7.5$ & $0.007-0.2$ & $4.0-35.5$ & $1.07-2.08$ & $8.5-180.6$ & $1.52-10.6$ \\
\hline 35 & $1-1.741$ & $0.084-0.26$ & $4.6-14.9$ & $1.17-3.09$ & $6.06-15.4$ & $1.029-1.93$ \\
\hline 36 & $1.08-5.5$ & 0.099-0.697 & $2.72-18.32$ & $3.0-49.09$ & $6.54-78.25$ & $1.48-24.57$ \\
\hline 37 & $0.147-0.66$ & $4.8-67.2$ & 7.8-104.4 & $103-1020$ & $15-167.2$ & $1.2-92$ \\
\hline 38 & $0.11-0.981$ & $0.063-1.4$ & $2.06-30.9$ & $1.26-31.6$ & $3.46-249.3$ & $1.02-18.5$ \\
\hline
\end{tabular}


overheating which is accompanied by discharges were identified. For equipment with overheating in the temperature range $150-300^{\circ} \mathrm{C}$, there is a high content of ethane and methane (defect No. 17) or ethane and ethylene (defect No. 18). The main reasons for such overheating are: increased heating of bolted connections, the presence of a short-circuited circuit, contamination of pipes and shells, clogging of coolant pipes, ferro-resonance overvoltages. The results of DGA for such defects are given in $[17,23]$. Of equipment in which overheating is accompanied by discharges and gas with the maximum content is ethane, the higher content of acetylene and ethylene is characteristic, as well as the excess of hydrogen content over methane content [16, 24].

When analysing defects for which ethylene $(23-31)$ is the gas with the maximum content by DGA results, attention should be paid to thermal defects with a temperature of $500-700^{\circ} \mathrm{C}$. For such defects $[13,17]$, the $\mathrm{C}_{2} \mathrm{H}_{4} / \mathrm{C}_{2} \mathrm{H}_{6}$ ratio is $1-3$. Such defects arise due to violations of contact connections, magnetic circuit defects and other damages. In equipment with overheating above $700^{\circ} \mathrm{C}$, an increased content of ethylene is observed in comparison with ethane (defects No. 25, 26). With increasing temperature, the ethylene content increases (defect No. 26), and at a temperature above $750^{\circ} \mathrm{C}$ (hot spot in the core), a significant increase in the acetylene content is observed. In equipment in which overheats with temperatures above $700^{\circ} \mathrm{C}$ are accompanied by discharges (28-31), a higher content of acetylene is observed, as well as the excess of hydrogen content over the content of methane [17].

Of greatest interest are defects for which the gas with the maximum content is acetylene. It is known $[19,20]$ that a significant content of acetylene occurs in discharges with high energy density as well as in overheating with a temperature above $750^{\circ} \mathrm{C}$. However, in an example given in [23], partial discharges are detected, while the maximum content is observed for acetylene (defect No. 32). Also note the defect No. 33. For this defect, the gas with the maximum content is acetylene, and high ethane content is also observed. Since the ethane content exceeds the ethylene content, $\mathrm{C}_{2} \mathrm{H}_{4} / \mathrm{C}_{2} \mathrm{H}_{6}<1$, which complicates the process of identifying this defect. The remaining defects, for which the gas with the maximum content is acetylene, are electric discharges of high energy, as well as discharges accompanied by overheating.

The performed analysis showed that the use of the values of gas ratios which are recommended by the standard IEC 60599 [1] made it possible to correctly diagnose $86.944 \%$ of units of equipment whose gas ratios are given in Table 4 . One of the main reasons for the establishment of an erroneous diagnosis or the failure of recognition is the discrepancy between the values of gas ratios in real equipment and the values of gas ratios regulated in [1]. For example, of 88 equipment units of low-density partial discharge, using the IEC 60599 standard, the correct diagnosis is for only 76 units of equipment. In 8 cases, the $\mathrm{C}_{2} \mathrm{H}_{4} / \mathrm{C}_{2} \mathrm{H}_{6}$ ratio was greater than 0.2 . In addition, for some defects, for example, low-energy arcing (defect No. 7 from Tables 3 and 4 ), the values of gas ratios correspond to several defects (partial discharges and high-energy discharges). That also can lead to the statement of erroneous diagnosis. The ranges of values of gas ratios shown in Table 4 allow to take into account these shortcomings and put a reliable diagnosis for a greater number of defects.

The values of the gas content for various types of defects listed in Table 3 can be considered reference trajectories and used to analyse the dynamics of the change in the content of gases during defect development.

\section{ANALYSIS OF THE DYNAMICS OF CHANGES IN THE CONTENT OF GASES IN THE DEVELOPMENT OF DEFECTS IN HIGH-VOLTAGE EQUIPMENT}

At the second stage of the research, the dependence of the gas content on the operating time before and during the development of defects in high-voltage equipment was analysed. The performed analysis made it possible to establish that, despite the increase in the concentration of gases accompanying the development of the defect, the percentage of gases varies insignificantly and is at a certain fixed level. As an example, Fig. 1 shows the dynamics of change in the gas content of oil in a transformer TDTN with a capacity of $40 \mathrm{MVA}$ with a voltage of $110 \mathrm{kV}$ of a leaky design, in which a high-temperature 


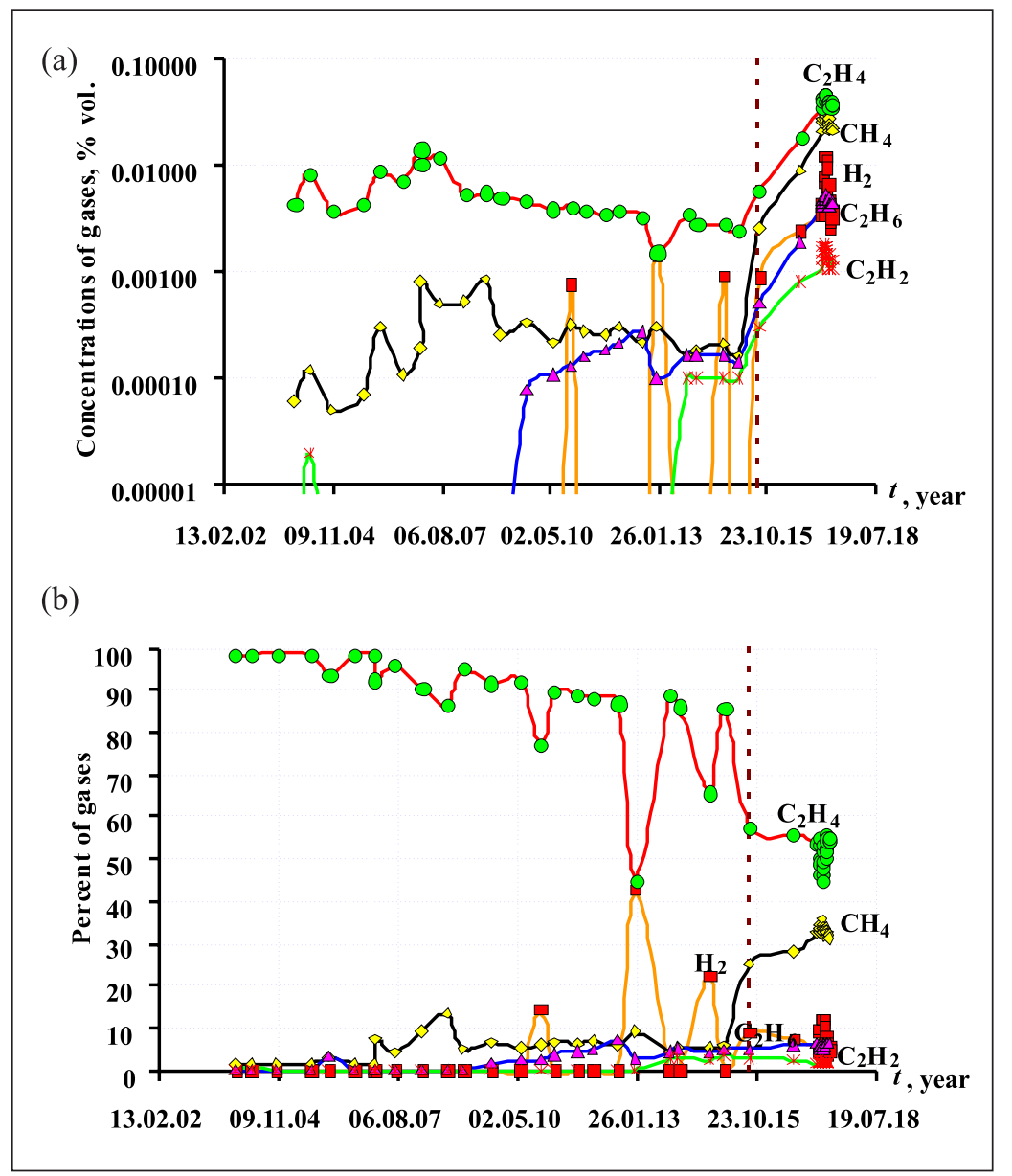

Fig. 1. Dynamics of change of gas content of oil in the transformer TDTN-40000/110: (a) values of gas concentrations, (b) percentage of gases

superheat with a temperature above $700^{\circ} \mathrm{C}$ was observed, which was accompanied by electric discharges. The vertical dotted line in Fig. 1 and in other figures indicates the date of appearance of the defect.

Analysing Fig. 1 it is easy to see that before the defect the values of concentrations (Fig. 1a) and the percentage of each of the gases (Fig. 1b) change randomly. In this case, the gases with the maximum content are mainly ethylene and methane. The content of hydrogen, ethane and acetylene is much less than the content of these two gases. As shown in [25] for non-hermetic equipment, this kind of gas content is typical and is caused both by the diffusion of gases into the atmosphere (low $\mathrm{H}_{2}$ content) and by intensive oxidation processes in the presence of free oxygen-air (high content of $\mathrm{C}_{2} \mathrm{H}_{4}$ ). When the defect develops, the values of the gas concentrations increase substantially (Fig. 1a), which is known [26], but the percentage of gases remains practically unchanged and remains at a strictly fixed level (Fig. 1b). In addition, as studies have shown for equipment with overheating above $700^{\circ} \mathrm{C}$, as well as for overheating with temperatures above $700^{\circ} \mathrm{C}$, which are accompanied by discharges, the change in gas content is of a similar nature. As an example, Fig. 2 shows the dynamics of changes in the gas content of oils in 3 transformers with such defects. In the transformer TDTN-40000/110 (Fig. 2a), based on the results of DGA, the core was overheated with a temperature above $700^{\circ} \mathrm{C}$ due to eddy currents. In the transformer TDTNG-40500/110 (Fig. 2b), overheating was detected, which was caused by a short circuit to the magnetic circuit tank and traces of discharges. In the transformer TRDNS-40000/220 (Fig. 2c), according to the results of DGA, overheating was detected with a temperature above $700^{\circ} \mathrm{C}$, which was 


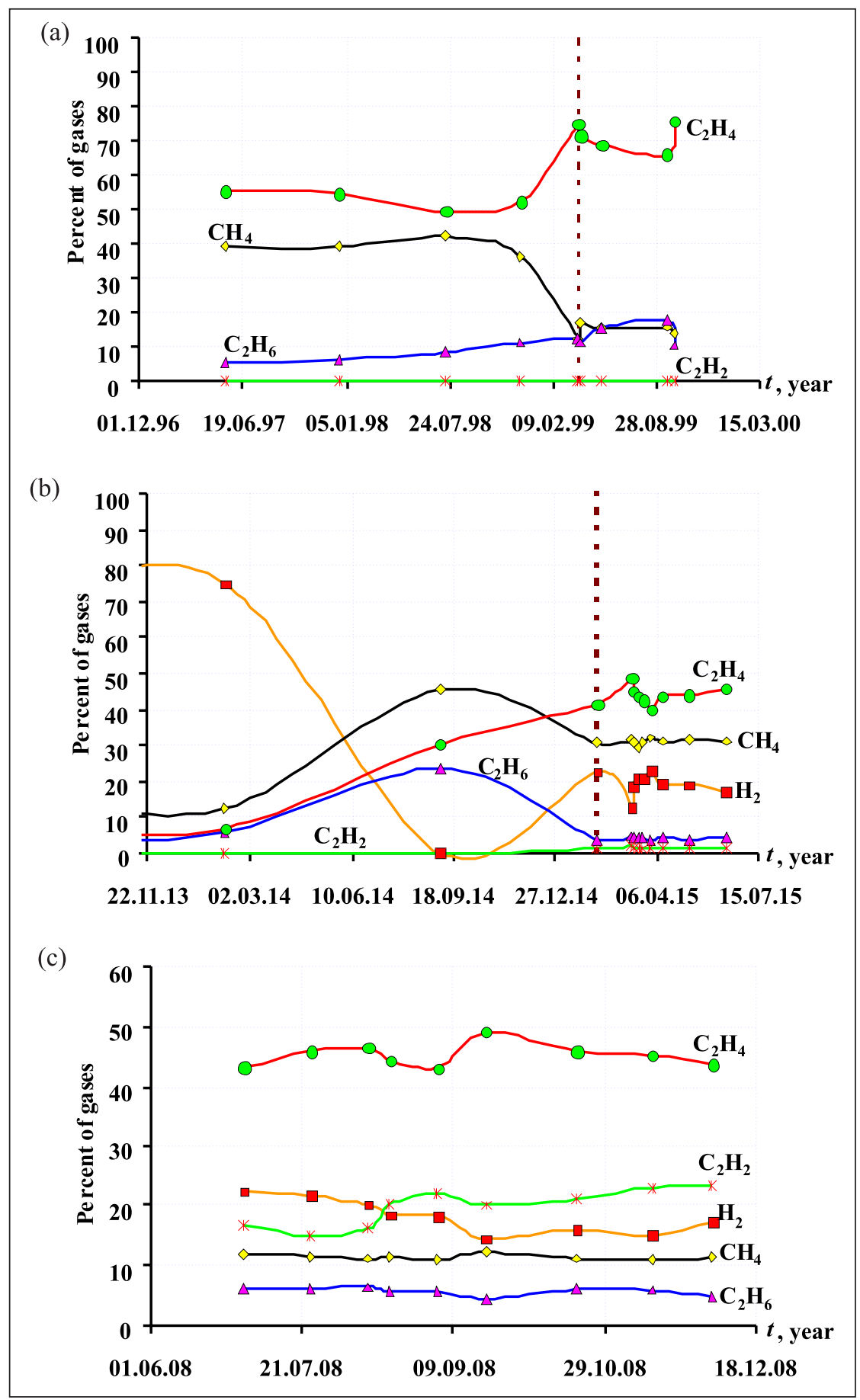

Fig. 2. Dynamics of changes in gas content of oils in transformers with overheating with temperatures above $700^{\circ} \mathrm{C}$ and also with overheating with temperatures above $700^{\circ} \mathrm{C}$, which are accompanied by discharges: (a) transformer TDTN-40000/110, (b) transformer TDTNG-40500/110, (c) transformer TRDNS-40000/220

accompanied by arc discharges (discharges occurred as a result of insulation loss of the pin). Comparing the curves in Fig. 2 it is easy to see the similar nature of the change in the gas content of oils (in particular, the symmetrical change in the content of $\mathrm{C}_{2} \mathrm{H}_{4}$ and $\mathrm{CH}_{4}$ ) in different transformers under high-temperature overheating and overheating accompanied by discharges. 
At the same time, the studies carried out have shown that for the defects, the type of which varies, the dynamics of the change in the gas content can vary significantly. As an example, Fig. 3 shows the dynamics of changes in the gas con- tent of autotransformers with spark discharges. In the autotransformer AT 300 MVA (Fig. 3a), the defect began with overheating in the temperature range $150-300^{\circ} \mathrm{C}$ (gas with the maximum ethane content), passing into partial

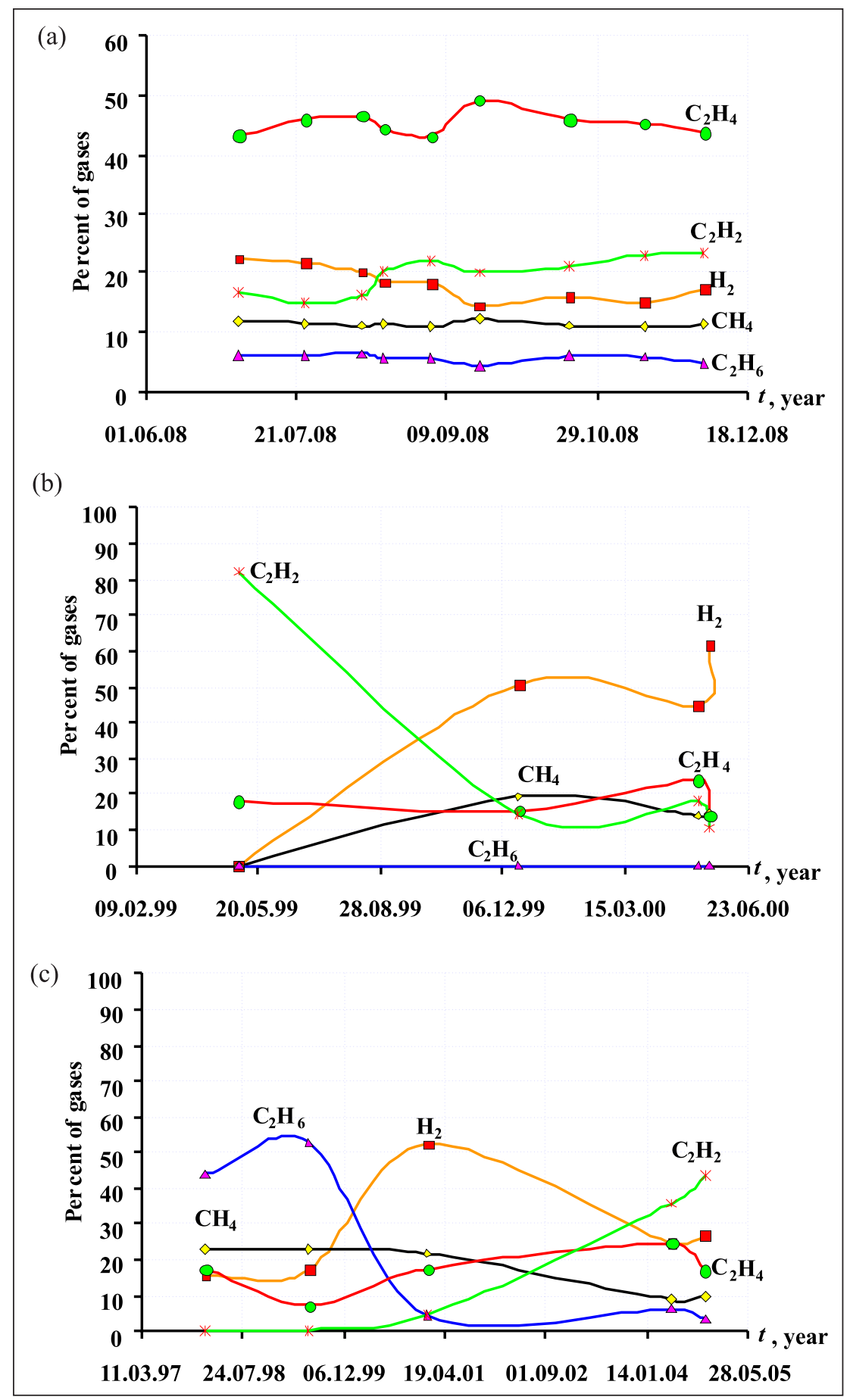

Fig. 3. Dynamics of changes in the percentage of gases in the oil equipment with spark discharges and high-energy discharges: (a) autotransformer $300 \mathrm{MVA}$, (b) autotransformer $220 \mathrm{kV}$, (c) transformer 20 MVA, $33 \mathrm{kV}$ 
discharges, and then into a spark discharge. In AT $220 \mathrm{kV}$ (Fig. 3b), the defect began with an arc discharge in oil (gas with a maximum concentration of $\mathrm{C}_{2} \mathrm{H}_{2}$ ), which gradually passed into a spark discharge. At the same time, as the defect develops, the content of limiting hydrocarbons and hydrogen increases against the background of a decrease in the ethylene and acetylene content. Figure $3 \mathrm{c}$ shows the dynamics of gas content change for a $20 \mathrm{MVA}, 33 \mathrm{kV}$ transformer in which high-energy discharges were detected by DGA results. It is noteworthy that the gas content for the first two DGA results already corresponded to overheating in the temperature range $150-300^{\circ} \mathrm{C}$ (gas with a maximum ethane concentration), then the defect shifted to spark discharges (gas with maximum hydrogen concentration), and only for the last two measurements the gas content corresponded to the high-energy discharges.

It is of fundamental importance that, no matter how the defect develops, the percentage content of the gases correspond to the defective state and tend to fixed values, which allows one to recognize defects at an early stage of their development. This is actually true for rapidly developing defects. As an example, Table 5 gives examples of the gas content of oil in damaged equipment. As it is shown in Table 5, for all four items of equipment listed in Table 5, the gas con- tent before and after the damage is significantly different. However, hydrocarbon gases and hydrogen were not present in oil samples taken before damage only in the RODC 750/110 reactor, which objectively did not prevent damage. At the same time, for all other equipment from Table 5, in oil samples that preceded damage, the gas content already indicated a defect. So, in the transformers of the "Nelson river" hydroelectric station (No. 1-2 of Table 5), the gas content of the oil indicated overheating in the temperature range $150-300^{\circ} \mathrm{C}$ (gas with the maximum ethane content). In the autotransformer ATDTSTN 125000, 220/110, the gas content of the oil indicated an arc discharge (gas with a maximum concentration of $\mathrm{C}_{2} \mathrm{H}_{2}$ ). Thus, an analysis of the gas content of the oil would prevent damage to this equipment.

\section{CONCLUSIONS}

1. The results of analysis of the percentage of gases in equipment with defects of different types are given. It is established that for different equipment with defects of the same type, the percentage of gases has similar values. The values of gas content of oils and gas ratios for 38 most common defects are given.

2. It is established that the development of defects in high-voltage equipment is accompanied

Table 5 . Values of percentage of gases in damaged equipment before and after damage

\begin{tabular}{|c|c|c|c|c|c|c|}
\hline \multirow{2}{*}{ No. } & \multirow{2}{*}{ Date of analysis } & \multicolumn{5}{|c|}{ Content of gases, $\%$} \\
\hline & & $\mathbf{H}_{2}$ & $\mathrm{CH}_{4}$ & $\mathrm{C}_{2} \mathrm{H}_{6}$ & $\mathrm{C}_{2} \mathrm{H}_{4}$ & $\mathrm{C}_{2} \mathrm{H}_{2}$ \\
\hline \multicolumn{7}{|c|}{ Hydroelectric station "Nelson river" Northern Canada, thermal breakdown of insulation [27] } \\
\hline \multirow{2}{*}{1} & 10 months before breakdown & 20.833 & 15.625 & 54.167 & 9.375 & 0.000 \\
\hline & After breakdown & 12.390 & 31.663 & 46.317 & 2.226 & 7.403 \\
\hline \multicolumn{7}{|c|}{ Hydroelectric station "Nelson river" Northern Canada, breakdown of insulation between coils [27] } \\
\hline \multirow{2}{*}{2} & 5 days before breakdown & 16.244 & 21.320 & 49.746 & 12.183 & 0.508 \\
\hline & After breakdown & 33.632 & 32.224 & 20.188 & 1.280 & 12.676 \\
\hline \multicolumn{7}{|c|}{ Reactor RODC 750/110, internal short circuit } \\
\hline \multirow{2}{*}{3} & 6 months before damage & - & - & - & - & - \\
\hline & After emergency shutdown & 41.450 & 14.312 & 0.000 & 20.074 & 24.164 \\
\hline \multicolumn{7}{|c|}{ Autotransformer ATDTSTN 125000, 220/110, high-energy discharges } \\
\hline \multirow{2}{*}{4} & Two months before damage & 0.000 & 0.000 & 0.000 & 39.024 & 60.976 \\
\hline & After damage & 14.093 & 10.945 & 3.748 & 34.183 & 37.031 \\
\hline
\end{tabular}


not only by the growth of gas concentrations, which is known and widely used, but also by stabilization of the percentage contents of gases at strictly defined levels. Since this stabilization takes place somewhat earlier than gas concentrations reach the boundary values, this effect can be used to detect developing defects at an early stage of their development, even before the values of gas concentrations exceed the boundary values, thus avoiding the destruction of equipment insulation and prolonging its resource.

3. The analysis of the obtained results showed that for different equipment with overheating above $700^{\circ} \mathrm{C}$ and also with overheating above $700^{\circ} \mathrm{C}$, which are accompanied by discharges, the change in gas content during the development of the defect has a similar character. This allows not only to detect these defects at an early stage of their development, but also to predict their possible appearance on the basis of an analysis of the dynamics of changes in gas content, which is impossible with the use of traditional criteria.

4. For defects the type of which changes in the course of their development, the dynamics of the change in the gas content can vary significantly. At the same time, no matter how the defect develops, the percentages of gases correspond to the defective state and tend to fixed values, which makes it possible to use the gas content of oils as an additional criterion for interpreting the results of analysis of gases dissolved in oil.

Received 15 January 2018 Accepted 20 February 2018

\section{References}

1. IEC Publication 60599, Interpretation of the analysis of gases in transformer and other oil med electrical equipment in \&, Geneva, Switzerland, 1999.

2. IEEE Guide for the Interpretation of Gases Generated in Oil-Immersed Transformers, IEEE StandARCd C57.104-2008, Feb. 2009.

3. Dornenburg E., Strittmater W. Monitoring oil cooling transformers by gas analysis. Brown Boveri Review. 1974. Vol. 61. P. 238-274.
4. Rogers R. R. IEEE and IEC codes to interpret incipient faults in transformers, using gas in oil analysis. IEEE Trans. on Electrical Insulation. 1978. No. 5(13). P. 349-354.

5. SOU-N EE 46.501: Diagnosis of oil-filled transformer equipment based on the results of chromatographic analysis of free gas with gas relay selected, i gases dissolved in insulating oil. Kiïv, 2007.

6. RD 153-34.0-46.302-00: Guidelines for the diagnosis of developing defects in transformer equipment based on the results of the chromatographic analysis of gases dissolved in oil. Moskva, 2001.

7. Popov G. V. The Problems of Diagnostics of Power Transformers. Ivanovo: State Power University named after V. I. Lenin, 2012. 176 p.

8. Duval M., Lamarre L. The Duval pentagon-a new complementary tool for the interpretation of dissolved gas analysis in transformers. IEEE Electrical Insulation Magazine. 2014. Vol. 30. Issue 6. P. 9-12.

9. Duval M. New techniques for dissolved gas-inoil analysis. IEEE Electrical Insulation Magazine. 2003. Vol. 19. No. 2. P. 6-15.

10. Ghoneim S., Merabtine N. Early stage transformer fault detection based on expertise method. International Journal of Electrical Electronics and Telecommunication Engineering. 2013. Vol. 44. P. 1289-1294.

11. Shutenko O. Analysis of graphical samples of gases constructed for chromatographic analysis of gases dissolved in oil for high-voltage power transformers with various types of defects. Bulletin of the National Technical University "KhPI". Collection of scientific papers. Series: Power reliability and energy efficiency, Kharkov: NTU "KhPI". 2017. No. 31(1253). P. 97-121.

12. Shutenko O., Jakovenko I. Fault diagnosis of power transformer using method of graphic images. 2017 IEEE International Young Scientists Forum on Applied Physics and Engineering (YSF-2017), October 17-20, 2017, Lviv, Ukraine. P. 66-69.

13. Bouchaoui L. Diagnostic des Transformateurs de Puissance par la Méthode d'Analyse des Gaz Dissous: Application des Réseaux de Neurones. 
Université Ferhat Abbas Sétif UFAS (ALGERIE), 2010. 155 p.

14. Ikbal Abulmageed Hameed, Saher Rady Farag. Monitoring power transformer using fuzzy logic. Journal of Engineering and Development. 2013. Vol. 17. No. 6. P. 146-163.

15. Hamed Ahadpour. A novel approach for diagnosis of power transformers internal faults using an electronic nose. Journal of Basic and Applied Scientific Research. 2011. Vol. 1. No. 7. P. 808-815.

16. Sherif S., Ghoneim M., Taha I. B. Artificial neural networks for power transformers fault diagnosis based on IEC code using dissolved gas analysis. International Journal of Control Automation and Systems. 2015. Vol. 4. No. 2. P. 18-21.

17. Duval M. A review of faults detectable by gas-inoil analysis in transformers. IEEE Electrical Insulation Magazine. 2002. Vol. 18. No. 3. P. 8-17.

18. Mohd Muhridza Bin Yaacob, Ahmed Raisan Hussein, Mohd Fauzi Bin Othman. DGA method-based ANFIS expert system for diagnosing faults and assessing quality of power transformer insulation oil. Modern Applied Science. 2016. Vol. 10. No. 1. P. 13-22.

19. Iyswarya Annapoorani K. Fault diagnosis of power transformer based on chemical properties of insulation oil. Journal of Chemical and Pharmaceutical Research. 2015. Vol. 7(3). P. 823-828.

20. Singh S., Bandyopadhyay M. N. Duval triangle: a noble technique for DGA in power transformers. International Journal of Electrical and Power Engineering. 2010. Vol. 4. No. 3. P. 193-197.

21. Kanika S., Ashish C. A novel association rule mining with IEC ratio based dissolved gas analysis for fault diagnosis of power transformers. International Journal of Advanced Computer Research. 2012. Vol. 2. No. 2. Issue 4. P. 34-44.

22. Gouda O. E., Saber Salem, Salah Hamdy El-Hoshy. Power transformer incipient faults diagnosis based on dissolved gas analysis. TELKOMNI$K A$ Indonesian Journal of Electrical Engineering. 2016. Vol. 17. No. 1. P. 10-16.

23. Uhunmwangho Roland, Omorogiuwa Eseosa. Artificial neural network approach to distribution transformers maintenance. International
Journal of Scientific Research Engineering Technology. 2015. Vol. 1. Issue 4. P. 62-70.

24. Kulkarni A. S., Swami P. S., Thosar A. G. Dissolved gas analysis of transformer oil using adaptive neuro-fuzzy inference system. International Journal of Scientific \& Engineering Research. 2016. Vol. 7. Issue 5. P. 1487-1491.

25. Shutenko O. Analysis of peculiarities of gas content of oils in defect-free transformers of untight construction. Bulletin of the National Technical University "KhPI". Collection of scientific papers. Series: Technique and Electrophysics of High Voltage, Kharkov: NTU "KhPI". 2017. No. 38(1260). P. 84-97.

26. Shutenko O. Features of dynamics of change of criteria used for interpretation of DGA results in power transformers with different types of defects. New in the Russian Electric Power Industry. 2017. No. 9. P. 30-49.

27. Aksenov Yu. P. Technical Condition Monitoring of High-Voltage Insulation of Electrical Energy Purposes in the Operation and Repairs. Moskva: Nauchtekhlitizdat, 2002.338 s.

\section{Oleg Shutenko}

\section{AUKŠTOS İTAMPOS IૃRANGOS GEDIMŲ DIAGNOSTIKA, PAGRİTA DUJŲ SUDĖTIES KITIMO DINAMIKOS ANALIZE}

\section{Santrauka}

Straipsnyje analizuojamas dujų kiekis alyvose, atsiradęs dèl ịvairių defektų aukštos ịtampos ịrenginiuose. Pateikti ir išanalizuoti tipiniai dujų kiekiai ir santykiai 38 labiausiai paplitusių defektų atvejais. Ištirta dujų kiekio kitimo dinamika įrangoje defektų gilejimo metu. Nustatyta, kad aukštos įtampos įrangos defektų gilejimą atspindi dujų koncentracijos augimas, kas yra žinoma ir plačiai taikoma, ir tai panaudotina stabilizuojant dujų procentus griežtai nustatytose ribose bei aptinkant defektus ankstyvoje fazejje.

Raktažodžiai: ištirpusių dujų analizè, gedimų diagnostika, aukštos įtampos įranga, gedimų diagnozè, dujų santykis, dujų procentas, dujų kiekio kitimo dinamika 